\title{
Strawponic for No-Till Potato Production
}

\author{
Ali Msheik, Mustapha Haidar*, Hadi Jaafar \\ Department of Agriculture, Faculty of Agriculture and Food Sciences, American University of Beirut, Beirut, Lebanon \\ Email: ${ }^{*}$ hhaidar@aub.edu.lb
}

How to cite this paper: Msheik, A., Haidar, M. and Jaafar, H. (2019) Strawponic for No-Till Potato Production. American Journal of Plant Sciences, 10, 2159-2169. https://doi.org/10.4236/ajps.2019.1012152

Received: October 17, 2019

Accepted: December 7, 2019

Published: December 10, 2019

Copyright (c) 2019 by author(s) and Scientific Research Publishing Inc. This work is licensed under the Creative Commons Attribution International License (CC BY 4.0).

http://creativecommons.org/licenses/by/4.0/

\begin{abstract}
Strawponic is an innovative and exotic system for growing potato on soil surface using crop straw as cover mulch. A field trial was carried out at the American University of Beirut in Lebanon to test the efficacy of this system for small potato producers. Barley (Hordeum vulgare) straw mulch at 25, 50 and $75 \mathrm{t} / \mathrm{ha}$ was used to cover potato tubers in no-till system. Potato plant number, height, number of shoots and leaves, root and shoot dry weight, and potato yield were collected. Results showed that all tested rates of straw significantly increased potato yield in comparison to the till system. Marketable yield was the highest with no-till potato at 50 and $75 \mathrm{t} / \mathrm{ha}$ compared to no-till potato at all tested surface straw rates. None of the treatments was harmful to potato plants compared to the till potato. This study could be a promising gate for production of potato for small-scale farmers.
\end{abstract}

\section{Keywords}

Potato, Straw, Mulch, No-Till

\section{Introduction}

Potato (Solanum tuberosum), an annual herbaceous plant, is regarded as one of the most important crops in Lebanon and the MENA region. Potatoes are considered to be the primary cash crop in Lebanon with their plantation covering 148,000 ha [1]. The Beq'aa and Akkar provinces are the main potato production areas, with about $68 \%$ and $19 \%$ of the total production, respectively [2].

Conservation agriculture is a new system that was introduced to Lebanon around 10 years ago. This system is becoming common in a few countries in the MENA region due to the economics of crop production and the improvement of water conservation and soil health by adding surface mulch [3] or by introducing the no-till potato system known as strawponic. The practice consists of placing the potato tubers on the soil surface and covers them with a thick layer of 
straw mulch.

Mulch is any dead material that is applied to the soil as a form of cover. Mulching has been practiced by farmers since ancient times. Its benefits include the control of soil erosion, water conservation and enhance the soils' organic matter content [4] [5]. Many studies revealed that soil moisture increases under straw mulch [4]. Moisture increases in mulched soil because of increased infiltration. When evaporation is decreased, water is conserved [6]. It was further noted that shading partly contributes to water conservation. The higher the amount of mulch applied to the soil, the more water is conserved. It was observed that light or heavy applications of mulch are almost similar in their effect in water conservation [7]. Mulch also leads to a reduction in the soil's surface temperature, and therefore it boosts dew formation [5].

Therefore, the objective of this research was to assess four surface straw mulch applications on growth and yield of no-till potato in semi-arid open field conditions. The research contributes to the understanding of impact of organic mulch on yield of potatoes in no-till system.

\section{Methodology}

\subsection{Site Information}

The experiment was conducted at the Advancing Research Enabling Communities Center (AREC), Lebanon. AREC is located in the Central Beq'aa plain with an altitude of around $1000 \mathrm{~m}$ above sea level at $34^{\circ} 54^{\prime \prime} \mathrm{N}$ latitude and $36^{\circ} 45^{\prime \prime} \mathrm{E}$ longitude. The soil is clayey (48.08\% clay, $35.85 \%$ silt, and $15.92 \%$ sand), basic $(\mathrm{pH}=7.80)$, non-saline $(\mathrm{EC}=0.00409 \mathrm{dS} / \mathrm{m})$, with $2.15 \%$ organic matter, $0.79 \%$ N, 16.9 ppm P, 415 ppm K, and 37.33\% $\mathrm{CaCO}_{3}$. Soil analysis was done according to Bashour and Sayegh [8]. Mean annual rainfall for 58 years of record at AREC is $521 \mathrm{~mm}$. The climate is classified as semi-arid, with an average annual grass reference evapotranspiration of $1.5 \mathrm{~m}, 70 \%$ of which occurs between April and September [9].

\subsection{General Experimental Procedures}

The field was fallow for almost 10 years, but full of weeds. Accordingly, it was cultivated one week prior to planting with a mold board. Finally the process of seed bed preparation was ended by disking and leveling the field to its best condition.

In no-till treatments, potato seeds "Spunta" were placed on the soil surface (Figure 1) and then were covered with a different layers of dry barley straw mulch (25, 50 and 75 tons/ha). The control treatment (tilled plots) was planted on the same day using a commercial two-row potato planter at a depth of $20 \mathrm{~cm}$. For no-till treatments, drip lines were placed on the top of the soil before placing potato tubers (Figure 2) on the soil surface. Drip lines were installed directly after planting for the till treatments. Irrigation scheduling was based on a percentage of recorded evapotranspiration measurements using an atmometer installed 


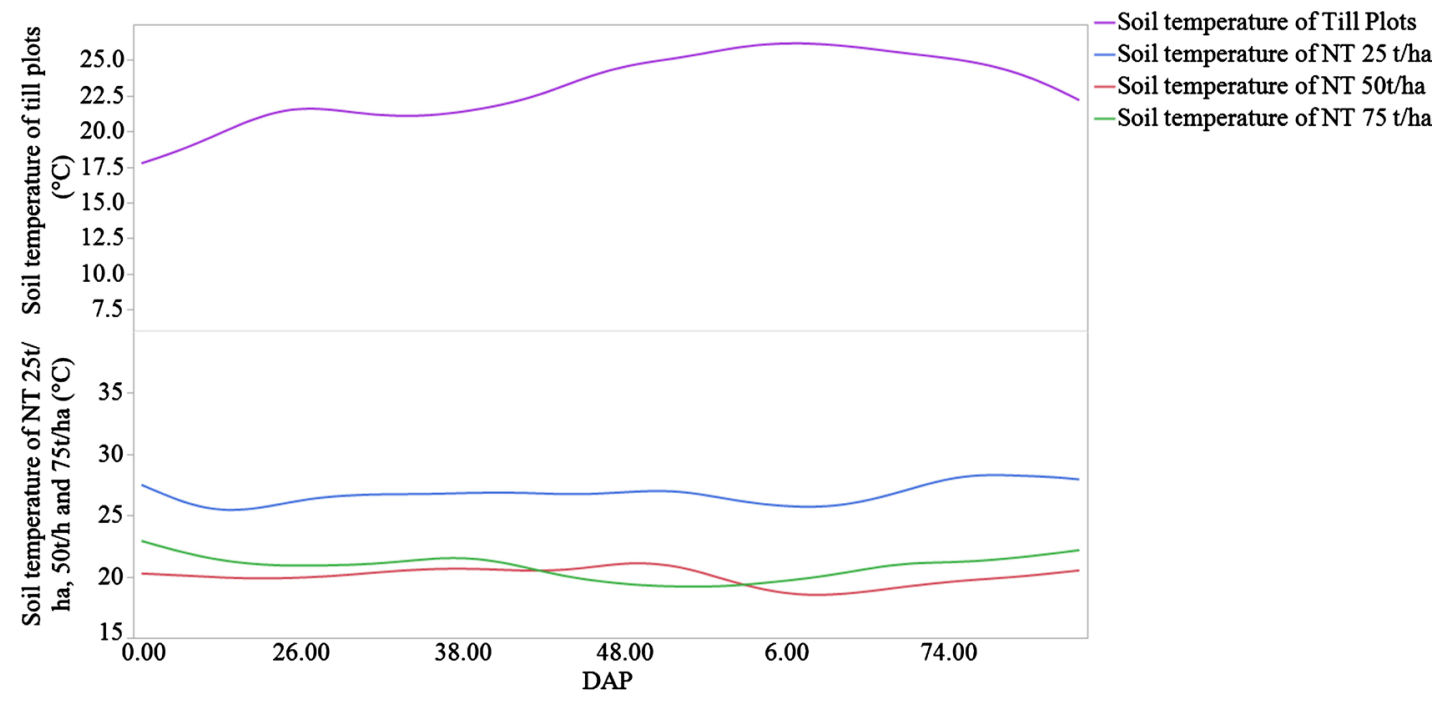

Figure 1. Daily soil temperature of till and no-till plots. DAP, Days after planting potato.

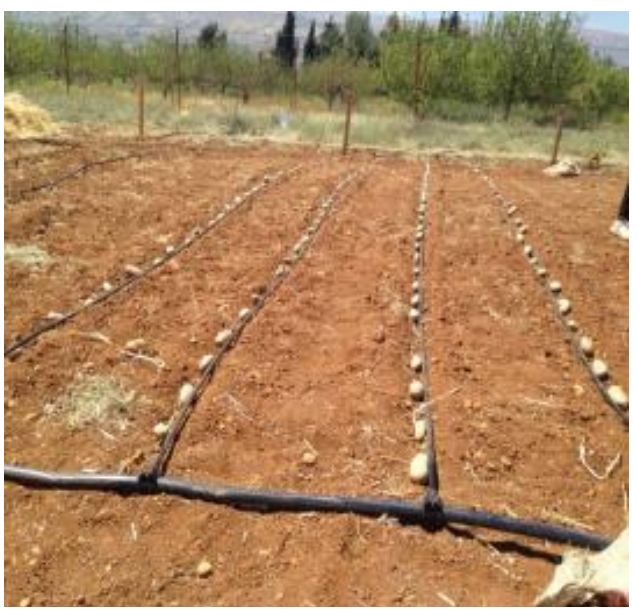

Figure 2. Placing potato tubers on the soil surface in no-till treatments.

in the field. The atmometer mimics alfalfa-reference evapotranspiration crop coefficients for potatoes were applied as per Allen [10] to determine crop evapotranspiration for the different growing stages of the crop. Granular fertilizer (15-15-15) was added to the soil surface, prior to planting at a rate of $500 \mathrm{Kg} / \mathrm{ha}$ using the band application method. Complimentary amounts of soluble fertilizers (20-20-20) were added in the drip irrigation systems every 15 days at a rate of $100 \mathrm{Kg} / \mathrm{ha}$.

\subsection{Mulching Rate and Sources}

Four barley mulch (Dry thick straw bales) rates were applied on the no-till treatments at $25 \mathrm{t} / \mathrm{ha}, 50 \mathrm{t} / \mathrm{ha}, 75 \mathrm{t} / \mathrm{ha}$ to be compared with the conventional potato cultivation. The straw was spread on the top of soil manually (Figure 3 ) ending up with a thickness of $15 \mathrm{~cm}, 30 \mathrm{~cm}$ and $50 \mathrm{~cm}$ for $25 \mathrm{t} / \mathrm{ha}, 50 \mathrm{t} / \mathrm{ha}$ and 75 $\mathrm{t} / \mathrm{ha}$ respectively. Baled barley mulches were obtained from a local farmer in a nearby village. 


\subsection{Harvesting Potato}

In no-till plots, potatoes were harvested by hand, by removing the straw from the top of the soil (Figure 4). While in the till plots, potato tubers were removed manually from the soil by using hoes.

\subsection{Experimental Measurements and Statistical Analyses}

Experimental plots were arranged in a randomized complete block design (RCBD) with four replicates. Blocks were separated by $2 \mathrm{~m}$ aisles. Each block was divided into 4 plots, a total of 16 plots/experimental site. The area of each plot was $10.08 \mathrm{~m}^{2}(3.6 \times 2.8 \mathrm{~m})$. Potato rows were $0.70 \mathrm{~m}$ apart and within row spacing was around $0.20 \mathrm{~m}$. Each plot consisted of 4 rows, for a total of 64 rows.

The data collected included the minimum and maximum soil temperatures at $20 \mathrm{~cm}$ depth for till treatment and at $0 \mathrm{~cm}$ soil surface for the no-till straw (Under the mulch treatment), number of plants in the middle two rows, shoot height (10 plants/plot), shoot number (10 plants/plot), the number of leaves (6 plants/plot), root and shoot dry weight (two plants from the edge rows), and yield quantity

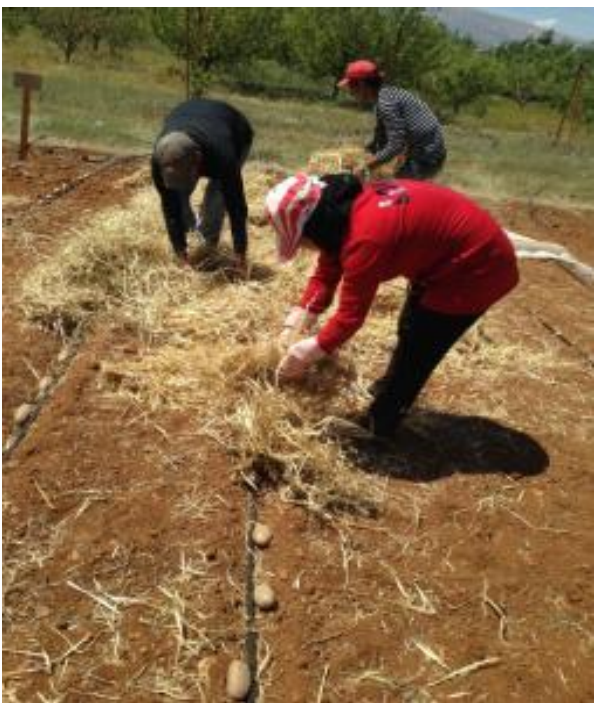

Figure 3. Placing and spreading straw mulch on potato in no-till treatments.

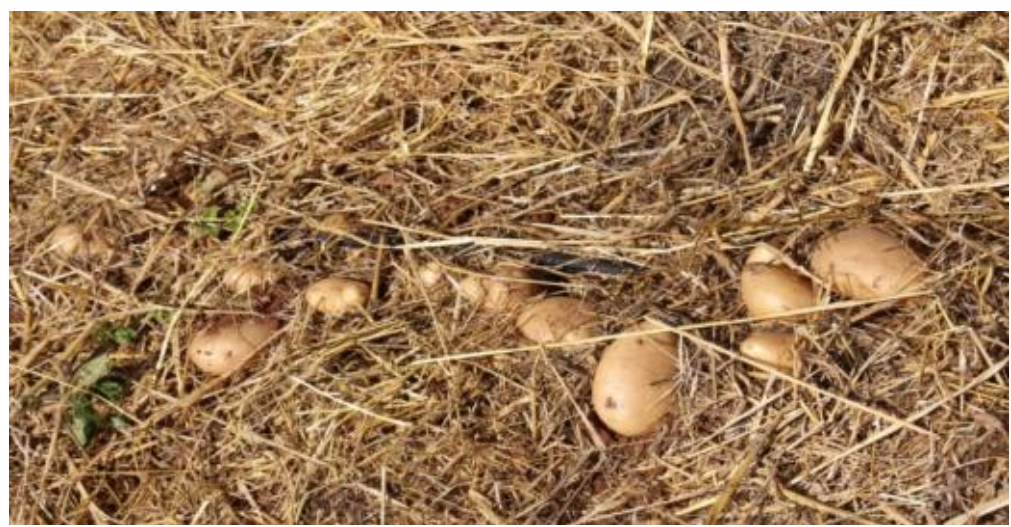

Figure 4. Potato tubers during harvesting season in the straw. 
and quality through counting and weighing the marketable and non-marketable tubers. The potato yield was determined by harvesting the middle two rows in each plot $\left(5.04 \mathrm{~m}^{2}\right)$. The yield quality was determined by separating harvested tubers into two classes: marketable ( $>6 \mathrm{~cm}$ diameter) and non-marketable tubers ( $<6 \mathrm{~cm}$ in diameter) according to Robinson et al. [11].

Statistical analyses were performed using STATA (2012). Treatment means were compared using one way ANOVA (analysis of variance) and Tukey's range test. Differences were considered significant at $\alpha=0.05$.

\section{Results and Discussion}

\subsection{Effect on Soil Temperature}

The maximum soil temperature observed was in till plots followed by no-till at $25 \mathrm{t} / \mathrm{ha}$ (Figure 3), while the minimum soil temperature was observed in no-till at $50 \mathrm{t} / \mathrm{ha}$ straw with a value of $16^{\circ} \mathrm{C}$. Many researchers have stressed on the effect of mulching on the soil temperature. Agele et al. [12] reported that mulching would reduce the soil temperature. In his research, Kar and Kumar [13] found that the soil temperature is dependent on the availability of straw mulch. The average difference between mulch and non-mulch was $4^{\circ} \mathrm{C}-6^{\circ} \mathrm{C}$ lower (Lower in mulch). Hay and Allen [14] recorded that the optimal soil temperature for potato production is between $15^{\circ} \mathrm{C}$ and $18^{\circ} \mathrm{C}$. In addition, reduced soil temperature may increase the phosphorous, potassium and organic carbon availability which could lead to higher yield in the mulched systems [13].

\subsection{Effect on Potato Growth}

Results show that the till potato $(0 \mathrm{t} / \mathrm{ha}$ mulch) significantly enhanced the shoot height, compared to the no-till potato at all the no till treatments $(25 \mathrm{t} / \mathrm{ha}, 50$ t/ha and $75 \mathrm{t} / \mathrm{ha}$ ), 45 days after planting (DAP, Table 1). However, with time shoot height in all no-till potato, 75 DAP were significantly higher than the till treatment. Similar results were obtained regarding plant number after 35 DAP. Except for no-till at straw rate of $75 \mathrm{t} / \mathrm{ha}$, plant numbers increased with time in all till and no-till treatments at 45 DAP. The no-till treatment at $75 \mathrm{t} / \mathrm{ha}$ straw slowed down the emergence of potato due to the thickness of the straw. Straw

Table 1. Effect of different mulching rates on potato shoot height and number of plants. DAP, Days After Planting Potato. Means followed by the same letter, within each column, do not significantly differ at the $5 \%$ level according to the LSD test.

\begin{tabular}{|c|c|c|c|c|c|c|c|c|c|c|c|}
\hline \multirow{3}{*}{$\begin{array}{c}\text { System } \\
\text { Till }\end{array}$} & \multirow{3}{*}{$\begin{array}{c}\text { Mulching rate } \\
\text { (t/ ha) } \\
0\end{array}$} & \multicolumn{4}{|c|}{$\begin{array}{c}\text { Shoot height }(\mathrm{cm}) \\
\text { DAP }\end{array}$} & \multicolumn{6}{|c|}{$\begin{array}{c}\text { Plant number } \\
\text { DAP }\end{array}$} \\
\hline & & \multicolumn{2}{|c|}{45} & \multicolumn{2}{|c|}{75} & \multicolumn{2}{|c|}{35} & \multicolumn{2}{|c|}{45} & \multicolumn{2}{|c|}{75} \\
\hline & & 51 & $\mathrm{a}$ & 66 & $\mathrm{~b}$ & 29 & $\mathrm{a}$ & 27 & $\mathrm{a}$ & 27 & $\mathrm{a}$ \\
\hline No-Till & 25 & 31 & $\mathrm{~b}$ & 78 & $a b$ & 24 & $\mathrm{a}$ & 29 & $\mathrm{a}$ & 26 & $a b$ \\
\hline No-Till & 50 & 35 & $\mathrm{~b}$ & 82 & a & 21 & $\mathrm{a}$ & 26 & $\mathrm{a}$ & 21 & $\mathrm{~b}$ \\
\hline No-Till & 75 & 26 & $\mathrm{~b}$ & 83 & $\mathrm{a}$ & 5 & $\mathrm{~b}$ & 14 & $\mathrm{~b}$ & 23 & $a b$ \\
\hline
\end{tabular}


thickness was almost $50 \mathrm{~cm}$ above the soil and took potato plant almost over 55 days to emerge above the straw. Boomsma and Vyn [15] found that thick mulch may produce shorter plants early in the season because of delayed emergence of crop shoots. Furthermore, cooler and wetter soil conditions resulting from a thick cover may lead to shorter plants. In her experiment, Mundy et al., [16] showed that in no-till system, the plant population and growth rate were lower than in till system early in the season. However, plant population and growth reached the same level as with plant in till system later in the season. Our observations showed that thick mulch in no-till plots at $75 \mathrm{t} /$ ha delayed emergence of potato plants and this resulted in shorter plants compared to till plots, up till 45 DAP. Shorter shoot heights and lower plant number in no-till straw potato may also be attributed to root growth behavior. Roots in no-till system were fluffy and extended mainly on the top of the soil surface. Tap roots look-like fiber roots. In other words, the taproot of potato plants is short forcing a fibrous growth pattern similar to grasses. While in till system, tap roots were obvious and clear and grown deeply beneath the soil.

Table 2 shows that none of the no-till straw treatments significantly reduced the potato shoot number 45 or 75 DAP compared to the till treatment $(0 \mathrm{t} / \mathrm{ha})$. The above results are in agreement with [17] [18] [19], who showed that application of surface dry grass mulch to sweet corn [17] and lettuce [18], increased shoot and leaf number compared to the no mulch treatments.

Regarding leaf number (Table 2), results showed that the till potato ( $0 \mathrm{t} / \mathrm{ha}$ mulch) significantly increased leaf number of potato shoots in comparison to all no-till straw potato treatments at various rates, 45 DAP. Leaf number in no-till straw potatoes at various rates increased with time. All no-till straw potato treatments significantly increased leaf number in comparison to till potato, 75 DAP. The same results were achieved by Liasu and Abdul [20], who recorded that mulching with wild sunflower straw resulted with a higher leaf number per tomato plants compared to the no mulch treatments. The growth and branch numbers of tomato plants [21] [22] were higher under straw mulch compared to the control without mulch.

The root and shoot dry weights were significantly higher in till potato $(0 \mathrm{t} / \mathrm{ha}$

Table 2. Effect of different mulching rates on potato shoot and leaf number. DAP, Days After Planting Potato. Means followed by the same letter, within each column, do not significantly differ at the $5 \%$ level according to the LSD test.

\begin{tabular}{|c|c|c|c|c|c|c|c|c|c|}
\hline \multirow{3}{*}{$\begin{array}{c}\text { System } \\
\text { Till }\end{array}$} & \multirow{3}{*}{$\begin{array}{c}\text { Mulching rate } \\
\text { (t/ha) } \\
0\end{array}$} & \multicolumn{4}{|c|}{$\begin{array}{c}\text { Shoot number } \\
\text { DAP }\end{array}$} & \multicolumn{4}{|c|}{$\begin{array}{c}\text { Leaf number } \\
\text { DAP }\end{array}$} \\
\hline & & \multicolumn{2}{|c|}{45} & \multicolumn{2}{|c|}{75} & \multicolumn{2}{|c|}{45} & \multicolumn{2}{|c|}{75} \\
\hline & & 4 & $\mathrm{a}$ & 4 & $\mathrm{a}$ & 13 & $\mathrm{a}$ & 15 & $\mathrm{~b}$ \\
\hline No-Till & 25 & 4 & $\mathrm{a}$ & 3 & $\mathrm{a}$ & 9 & $\mathrm{~b}$ & 19 & $\mathrm{a}$ \\
\hline No-Till & 50 & 4 & $\mathrm{a}$ & 3 & $\mathrm{a}$ & 9 & $\mathrm{~b}$ & 18 & a \\
\hline No-Till & 75 & 3 & $\mathrm{a}$ & 3 & $\mathrm{a}$ & 6 & $c$ & 20 & $\mathrm{a}$ \\
\hline
\end{tabular}


mulch) in comparison to all no-till straw treatments at various rates of straw, 45 DAP (Table 3). However, the shoot and root dry weight for most no-till straw potato increased with time, (after $117 \mathrm{DAP}$ ) with some variation among treatments. Root dry weight in no-till straw potato at $75 \mathrm{t} / \mathrm{ha}$ was significantly lower than the till potato $(0 \mathrm{t} / \mathrm{ha}$ mulch $), 117 \mathrm{DAP}$. In general most no-till straw treatments produced lower shoot dry weight $45 \mathrm{DAP}$ in comparison to the till potato (0 t/ha mulch). However, shoot dry weight increased with time (117 DAP). The difference in root and shoot dry weight between no-till straw and till treatments is an indication that potato plants in till systems are longer and bigger than the shallow roots in no-till straw plots. It could be that roots penetrate deeply in the soil (up to $40 \mathrm{~cm}$ ). However, roots in no till treatments have a higher density on soil surface than the till treatments; Roots dominated the upper top layers of the soil, yet they spread vigorously with high density of root hairs.

Table 4 shows that no-till straw potatoes at all tested rates significantly produced higher marketable tuber number than the till potato. No-till potatoes at 50 and $75 \mathrm{t} /$ ha straw gave the highest marketable tubers in comparison to the rest of the treatments. Also, results show that the no-till straw potato at $75 \mathrm{t} /$ ha gave the lowest nonmarketable tubers in contrast to the rest of treatments. This is due to the fact that potato tubers in no-till are produced on the soil surface, and they are surrounded by the mulch similar to a bird's nest. Hence they won't be affected by soil compaction. Many researchers have reported the effect of mulch

Table 3. Effect of different mulching rates on potato root and shoot dry weight. DAP, Days After Planting Potato. Means followed by the same letter, within each column, do not significantly differ at the $5 \%$ level according to the LSD test.

\begin{tabular}{|c|c|c|c|c|c|c|c|c|c|}
\hline \multirow[t]{2}{*}{ System } & \multirow{2}{*}{$\begin{array}{l}\text { Mulching rate } \\
\text { (t/ ha) }\end{array}$} & \multicolumn{4}{|c|}{$\begin{array}{c}\text { Root dry weight (g) } \\
\text { DAP }\end{array}$} & \multicolumn{4}{|c|}{$\begin{array}{c}\text { Shoot dry weight }(\mathrm{g}) \\
\text { DAP }\end{array}$} \\
\hline & & \multicolumn{2}{|c|}{45} & \multicolumn{2}{|c|}{117} & \multicolumn{2}{|c|}{45} & \multicolumn{2}{|c|}{117} \\
\hline Till & 0 & 15 & $\mathrm{a}$ & 9 & $\mathrm{a}$ & 97 & a & 69 & $\mathrm{~b}$ \\
\hline No-Till & 25 & 3 & b & 10 & $\mathrm{a}$ & 27 & b & 105 & $\mathrm{a}$ \\
\hline No-Till & 50 & 5 & b & 8 & $\mathrm{a}$ & 33 & b & 58 & b \\
\hline No-Till & 75 & 3 & $\mathrm{~b}$ & 4 & b & 14 & c & 80 & b \\
\hline
\end{tabular}

Table 4. Effect of different mulching rates on potato marketable, non-marketable tuber and total number of tubers. Means followed by the same letter, within each column, do not significantly differ at the $5 \%$ level according to the LSD test.

\begin{tabular}{cccccccc}
\hline System & $\begin{array}{c}\text { Mulching rate } \\
\text { (t/ ha) }\end{array}$ & \multicolumn{2}{l}{ Harvested tubers number $(1000 / \mathrm{ha})$} & \multicolumn{2}{c}{$\begin{array}{c}\text { Total number of } \\
\text { harvested tubers } \\
(1000 / \mathrm{ha})\end{array}$} \\
\cline { 3 - 6 } Till & 0 & 33 & $\mathrm{c}$ & 466 & $\mathrm{a}$ & 500 & $\mathrm{a}$ \\
No-Till & 25 & 68 & $\mathrm{~b}$ & 390 & $\mathrm{ab}$ & 458 & $\mathrm{a}$ \\
No-Till & 50 & 95 & $\mathrm{~b}$ & 391 & $\mathrm{ab}$ & 486 & $\mathrm{a}$ \\
No-Till & 75 & 123 & $\mathrm{a}$ & 290 & $\mathrm{~b}$ & 412 & $\mathrm{a}$ \\
\hline
\end{tabular}


on the number of fruits such as bell peppers [23], sweet corn [17], tomatoes [24] and chili plants [25].

Results show that all no-till straw potato at all tested rates significantly increased marketable yield in comparison to the till potato (Table 5). High marketable yield was obtained with no-till straw potato at 50 and $75 \mathrm{t} /$ ha in comparison to the rest of till and no-till potato. Highest total potato yield was obtained with no-till straw at $50 \mathrm{t} / \mathrm{ha}$. Many researchers have reported the effect of mulch on the yield. Mundy [16] evaluated the effects of various tillage treatments, conventional tillage, no-tillage, subsurface tillage on crop yield. After comparing the yields of potato in different systems, Mundy [16] reported that there were no significant differences in potato yields between no-tillage and subsurface tillage. In their experiment, Kar and Kumar [13], noted that air dry tuber yields in mulched plots were $14.9 \mathrm{t} /$ ha compared to the non-mulched plot with $11.2 \mathrm{t} / \mathrm{ha}$. They also reported that higher yields were observed in the straw mulch treatments than the till system. They concluded that this could be related to higher conservation of soil moisture, suitable temperature, high phosphorous and potassium under the straw mulch. Chili [25], okra [26], tomatoes [21], and peppers [17] produced a higher yield in mulch compared to non-mulched treatments. Komla [27] reported that no significant differences in marketable fruits of sweet pepper were observed between different mulching treatments. He added that dry rice husks, empty palm bunches and cocoa pods increased marketable yield compared to the non-mulched control treatments.

\subsection{Economical Assessment}

Our observations show that growing potatoes using straw cover (no-till) during the first season is not economically feasible; however, on the long term (second season) and because straw can be reused on the following season, the price of any additional straw will be negligible. Hence keeping everything else constant the gross margin of mulch treatments will be more profitable than till treatments in the second season. The no-till system for potato production could be feasible for small scale farmers in the MENA region for various reasons. Among them are the availability of cheap laborers, it is a sustainable technology, profitable and ecologically friendly.

Table 5. Effect of different mulching rates on potato marketable, non-marketable and total weight of tubers. Means followed by the same letter, within each column, do not significantly differ at the $5 \%$ level according to the LSD test.

\begin{tabular}{|c|c|c|c|c|c|c|c|}
\hline \multirow{3}{*}{$\begin{array}{c}\text { System } \\
\text { Till }\end{array}$} & \multirow{3}{*}{$\begin{array}{c}\text { Mulching rate } \\
\text { (t/ha) } \\
0\end{array}$} & \multicolumn{4}{|c|}{ Tuber weight $(1000 \mathrm{~kg} / \mathrm{ha})$} & \multirow{2}{*}{\multicolumn{2}{|c|}{$\begin{array}{l}\text { Total weight of tubers } \\
\qquad(1000 \mathrm{~kg} / \mathrm{ha})\end{array}$}} \\
\hline & & \multicolumn{2}{|c|}{ Marketable } & \multicolumn{2}{|c|}{ Non-marketable } & & \\
\hline & & 9 & c & 34 & a & 42 & $\mathrm{~b}$ \\
\hline No-Till & 25 & 20 & $\mathrm{~b}$ & 27 & $\mathrm{ab}$ & 47 & $\mathrm{~b}$ \\
\hline No-Till & 50 & 28 & a & 28 & $\mathrm{ab}$ & 56 & a \\
\hline No-Till & 75 & 31 & $\mathrm{a}$ & 21 & $\mathrm{~b}$ & 52 & $\mathrm{ab}$ \\
\hline
\end{tabular}




\section{Conclusion}

It can be concluded from this study that the highest total yield was in no-till straw potato at $50 \mathrm{t} / \mathrm{ha}$. This study provides innovative and sustainable information for growing potato in no-till systems. It will help small potato growers produce potato with less energy, fewer weeds, and less irrigation water, but with high tuber yield of potato. This system also has a few ecological advantages over the conventional system since it lacks seedbed preparation (hence less soil erosion and less pollution). Further studies should be done to investigate the benefit of other crop residues on potato growth and yield.

\section{Conflicts of Interest}

The authors declare no conflicts of interest regarding the publication of this paper.

\section{References}

[1] Darwish, T., Atallah, T., Hajhassan, S. and Chranek, A. (2003) Management of Nitrogen by Fertigation of Potato in Lebanon. Nutrient Cycling in Agroecosystems, 67, 1-11.

[2] Abou-Jawdah, Y., Sobh, H. and Saad, A.T. (2001) Incidence of Potato Virus Diseases and Their Significance for a Seed Certification Program in Lebanon. Phytopathologia Mediterranea, 40, 113-118.

[3] Loss, S., Haddad, A., Khalil, Y., Alrijabo, A., Feindel, D. and Piggin, C. (2015) Evolution and Adoption of Conservation Agriculture in the Middle East. In: Farooq, M. and Siddique, K., Eds., Conservation Agriculture, Springer, Cham.

[4] Döring, T.F., Brandt, M., Heß, J., Finckh, M.R. and Saucke, H. (2005) Effects of Straw Mulch on Soil Nitrate Dynamics, Weeds, Yield and Soil Erosion in Organically Grown Potatoes. Field Crops Research, 94, 238-249. https://doi.org/10.1016/j.fcr.2005.01.006

[5] Jacks, G.V., Brind, W.D. and Smith, R. (1955) Mulching. Commonwealth Bur. Soil Sci. Tech. Comm., No. 49.

[6] Ayanlaja, S.A. and Sanwo, J.O. (1991) Management of Soil Organic Matter in the Farming Systems of the Low Land Humid Tropics of West Africa: A Review. Soil Technology, 4, 265-279. https://doi.org/10.1016/0933-3630(91)90006-9

[7] Russel, J.C. (1940) The Effect of Surface Cover on Soil Moisture Losses by Evaporation. Science Society of America Journal, 4, 65-70. https://doi.org/10.2136/sssaj1940.036159950004000C0012x

[8] Bashour, I.I. and Sayegh, A.H. (2007) Methods of Analysis for Soils of Arid and Semi-Arid Regions. Food and Agriculture Organization of the United Nations, Rome.

[9] Jaafar, H.H., Khraizat, Z., Bashour, I. and Haidar, M. (2017) Determining Water Requirements of Biblical Hyssop Using an ET-Based Drip Irrigation System. Agricultural Water Management, 140, 107-117. https://doi.org/10.1016/j.agwat.2016.11.008

[10] Allen, R.G. (1998) Crop Evapotranspiration-Guidelines for Computing Crop Water requirements-FAO Irrigation and Drainage Paper 56. FAO, Rome, D05109.

[11] Robinson, D., Monks, D. and Monaco, J. (1996) Potato (Solanum tuberosum) To- 
lerance and Susceptibility of Eight Weeds to Rimsulfuron with and without Metribuzin. Weed Technology, 10, 29-34. https://doi.org/10.1017/S0890037X00045668

[12] Agele, S.O., Iremiren, G.K. and Ojeniyi, S.O. (2000) Effect of Tillage and Mulching on the Growth, Development and Yield of Late Season Tomato (Lycopersicon esculentum) in the Humid South of Nigeria. The Journal of Agricultural Science, 134, 55-59. https://doi.org/10.1017/S0021859699007273

[13] Kar, G. and Kumar, A. (2007) Effects of Irrigation and Straw Mulch on Water Use and Tuber Yield of Potato in Eastern India. Agricultural Water Management, 94, 109-116. https://doi.org/10.1016/j.agwat.2007.08.004

[14] Hay, R.K.M. and Allen, E.J. (1978) Tuber Initiation and Bulking in the Potato (Solanum tuberosum) under Tropical Conditions: The Importance of Soil and Air Temperature. Tropical Agriculture, 55, 289-295.

[15] Boomsma, C.R. and Vyn, T.J. (2007) Plant-to-Plant Uniformity Is Essential for Optimum Yield in No-Till Continuous Corn. Purdue Extension AY.

[16] Mundy, C., Creamer, N.G., Wilson, L.G., Crozier, C.R. and Morse, R.D. (1999) Soil Physical Properties and Potato Yield in No-Till, Subsurface-Till, and Conventional-Till Systems. HortTechnology, 9, 240-247. https://doi.org/10.21273/HORTTECH.9.2.240

[17] Norman, J.C., Asante, I. and Nartey, I.T. (2002) Mulching Effects on Growth, Partitioning and Yield of Sweet Corn. Ghana Journal of Horticulture, 1, 16-20.

[18] Moniruzzaman, M. (2006) Effects of Plant Spacing and Mulching on Yield and Profitability of Mulch in Arid Region of India. Agrochemica, 31, 183-202.

[19] Tswanya, M.N. and Olaniyi, J. (2016) Effects of Selected Mulches and Their Mulching Rate on Growth and Fruit Yield of Tomato Variety in the Southern Guinea Savanna of Nigeria. Direct Research Journal of Agriculture and Food Science, 4, 339-344.

[20] Liasu, M.O. and Abdul kabir, K.A. (2007) Influence of Lithonia Divers Folia Leaf Mulch and Fertilizer Application on the Growth and Yield of Potted Tomato Plants. American-Eurasian Journal of Agriculture and Environmental Science, 2, 335-340.

[21] Gandhi, N. and Bains, G.S. (2006) Effect of Mulching and Date of Transplanting on Yield Contributing Characters of Tomato. PAU Agricultural Research Journal, 43, 6-9.

[22] Ojeniyi, S.O., Awodun, M.A. and Odedina, S.A. (2007) Effect of Animal Manure, Amended Spent Grain and Cocoa Husk on Nutrient Status, Growth and Yield of Tomato. Middle East Journal of Scientific Research, 2, 33-36

[23] Manuel, C.P., Allison, M.D. and Stafford, M.A.C. (2000) Comparison of Organic and Synthetic Mulch for Bell Pepper Production at Three Levels of Drip Irrigation. Proceedings of the Florida State Horticultural Society, 113, 234-236.

[24] Awodoyin, R.O., Ogbeide, F.I. and Oluwole, O. (2007) Effects of Three Mulch Types on the Growth and Yield of Tomato (Lycopersicon esculentum Mill.) and Weed Suppression in Ibadan, Rainforest-Savanna Transition Zone of Nigeria. Tropical Agricultural Research and Extension, 10, 53-60.

[25] Venkanna, Y. (2008) Effect of Mulches, Organics and Organic Solutions on Growth, Yield and Quality of Chilli (Capsicum annuum 1.) Cv. Byadagidabbi in Northern Transition Zone of Karnataka. Thesis, University of Agricultural Science, Dharwad, Karnataka, India.

[26] Abd El-Kader, A.A., Shaaban, S.M. and Abd El-Fattah, M. S. (2010) Effect of Irrigation Level and Organic Compost on Okra (Abelmoschus esculentus 1.) Grown in 
Sandy Calcareous Soil. Agriculture and Biology Journal of North America, 1, 225-231. http://www.fao.org/potato-2008/en/potato/index.html https://doi.org/10.5251/abjna.2010.1.3.225.231

[27] Komla, A.N. (2013) Effect of Organic Mulch on Growth and Yield of Sweet Pepper (Capsicum annuum L.) Doctoral Dissertation, University of Ghana, Ghana. 